\title{
A FOgYATÉKOSSÁg REPREZENTÁCIÓJA AZ ÁlTALÁNOS ISKOLÁK MAGYAR IRODALOM TANANYAGÁHOZ KAPCSOLÓDÓ IRODALMI MÜVEKBEN
}

\author{
GULYA NIKOLETTA MÁRIAª - FEHÉRVÁRI ANIKÓb,* \\ ${ }^{a}$ Eötvös Loránd Tudományegyetem Neveléstudományi Doktori Iskola \\ 'Eötvös Loránd Tudományegyetem Neveléstudományi Intézet
}

Az irodalmi alkotások jól alkalmazhatók az oktatásban arra, hogy a tanulók megismerkedjenek a társadalom sokszínűségével és annak kulturális összefüggéseivel, amennyiben megfelelően ábrázolják ezeket a társadalmi csoportokat.

Jelen írás célja, hogy a tartalomelemzés módszerével feltárja és elemezze a magyar általános iskolák tananyagához kapcsolódó irodalmi szemelvénye fogyatékossággal kapcsolatos tartalmait.

A kutatás eredményei rávilágítanak, hogy a vizsgált irodalmi szemelvényekben a fogyatékossággal élő szereplők rendkívül alulreprezentáltak és sztereotip módon ábrázoltak, ezáltal erősíthetik a tanulók fogyatékossággal élő emberekkel kapcsolatos elöítéleteit, így feldolgozásukkor hangsúlyt kell fektetni a sztereotip tartalmak tisztázására.

Kulcsszavak: fogyatékosság, gyermekirodalom, tartalomelemzés, inkluzív tananyag

Literary works are a readily available resource in education to help students learn about the diversity of society and its cultural contexts, as long as they depict these social groups appropriately.

The study aimed to identify the different recurring patterns of the disability conception within the content of youth literature in primary education, employing content analysis.

The results of the research reveal that in the examined literary works people with disabilities are extremely underrepresented and depicted stereotypically. This way of representation can reinforce students' negative attitude towards people with disabilities, therefore the stereotypical content should be clarified and discussed during the lessons.

Keywords: disability, youth literature, content analysis, inclusive curriculum

\footnotetext{
* Levelező szerző: Fehérvári Anikó, ELTE PPK, 1075 Budapest, Kazinczy u. 23-27.

E-mail: fehervari.aniko@ppk.elte.hu
} 
$\mathrm{A}$ fogyatékossággal élő emberek csoportja alkotja a világ egyik legjelentősebb számú kisebbségét (Riley 2005). A többségi társadalom fogyatékossághoz füződő viszonya állandóan változik, a fogyatékossággal élő emberekkel kapcsolatos évezredes, sok esetben negatív sztereotípiák kultúráktól függetlenül megjelennek a művészeti alkotásokban (Flamich-Hoffmann 2015), „egyetemes jelenlétükkel meghatározva a fogyatékossággal élő személyek fogadtatását, megítélését" (Flammich-Hoffmann 2014: 58.). A fent említett sztereotípiák nyomon követhetőek az irodalmi alkotásokban is. A magyarországi általános iskolákban használt magyar irodalom tankönyvek számos irodalmi alkotást tartalmaznak. Az irodalmi művek üzeneteket hordoznak a világról, amelyben élünk, közvetítik kulturális örökségünket (Ullab-Ali-Naz 2014). Az irodalmi művek az emberi viszonyok valamennyi rétegét képesek bemutatni a szóbeli közlés által (Gödöné 2011). Foucault (1991) a diskurzus hatalmának összefüggésében úgy értelmezi a társadalmi jelenségeket, mint amelyek a róluk szóló diskurzusok által léteznek. Tehát, egy társadalmi csoport tagjainak az irodalmi művekben megjelenő (vagy meg nem jelenő) ábrázolásmódja hatással lehet az olvasók világról alkotott képére, illetve meghatározó lehet egy adott társadalmi csoporttal kapcsolatos szemléletmódjuk kialakításában (Hardin-Preston 2011).

Jelen tanulmány arra igyekszik választ találni, hogy a magyarországi általános iskolai irodalomtankönyvek és -olvasókönyvek irodalmi szemelvényeiben hogyan jelenik meg a fogyatékosság témája, és ez az ábrázolásmód milyen hatással lehet a tanulók fogyatékossággal élő emberekkel kapcsolatos szemléletmódjára.

\section{Inklúzió és oktatás}

A sajátos nevelési igényü tanulók inkluzív oktatása fontos célja a nemzetközi oktatáspolitikáknak (O’Brien-Kudlacek-Howe 2009). Az 1980-as évek második felétől számos országban elterjedt az inklúziós szemléletmód, amely a sajátos nevelési igényü gyermekek részvételét hivatott képviselni az oktatásban, képességeik és fejlődési ütemük figyelembevételével (Köpatakiné 2006).

$\mathrm{A} z$ 1993. évi közoktatási (LXXIX.) törvény Magyarországon is megnyitotta a fogyatékossággal élő tanulók előtt azt a lehetőséget, hogy többségi iskolákban ép társaikkal együtt tanulhassanak. A befogadó osztálytermek növekvő száma több kihívást tartogatott, illetve tartogat napjainkban is az oktatás-nevelés színterén. Egyik jelentős feladat a fogyatékossággal élő tanulók beilleszkedése az osztályokba. Az erre irányuló kutatások azt mutatják, hogy a többségi tanulók és fogyatékossággal élő társaik között általában nem alakul ki baráti kapcsolat, a fogyatékossággal élő tanulók sokszor elszigetelten, magányosan élik mindennapjaikat többségi társaik között (McDougall et al. 2004; Schiemer 2017; Szekeres 2012). Annak ellenére, hogy fizikailag a többségi rendszerben vannak, továbbra is elszigeteltek maradnak az osztályban (Guinagh 1980). Ennek tükrében nyilvánvaló, hogy a fogyatékossággal élő tanulókat nem elég behelyezni az osztályközösségbe, hiszen ez a folyamat nem garantálja befogadásukat.

A fogyatékossággal élő emberek társadalmi befogadását nagyban hátráltatja, hogy a többségi társadalom nem rendelkezik kellő mennyiségű releváns információval a fogyatékosság témájával kapcsolatban (Connor-Bejoian 2014). Ez a megállapítás igaz a befogadó osztályközösségek esetében is. A szakemberek véleménye szerint a fogadó osztály tanulóit fel kell készíteni a fogyatékossággal élő tanuló érkezésére (Szekeres-Perlusz- 


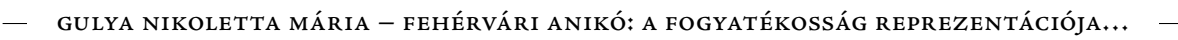

Takács 2012), hiszen osztályközösségi befogadását jelentősen meghatározza osztálytársainak fogyatékossággal kapcsolatos attitüdje.

\section{A fogyatékossággal élő emberekkel kapcsolatos előítéletek}

Az elöítéletes gondolkodás kialakulására, müködésmódjára és hatásaira vonatkozóan két vizsgálati nézőpont különböztethető meg, az értékelvű, illetve a leíró. Mindkét megközelítés lehet kontextualista, amely szerint az elöítéletesség nem eredendő pszichés adottság, hanem mindig társadalmi kontextusba ágyazott, azaz személyek vagy csoportok közötti interakciók eredménye (Erős 2007). A másik nézőpont szerint mindkét szemléletmód lehet intrapszichikus, amely nem elsősorban a személyt ért társadalmi hatásokra, hanem a személyen belüli kognitív folyamatokra koncentrál az elöítéletes gondolkodás kialakulása okán.

Bármelyik megközelítést is alkalmazzuk, legyen az társadalmi vagy kognitív, mindkettő szerint a szocializációnak kitüntetett szerep jut (Pléb 2017). A szocializáció révén sajátítjuk el a sztereotípiákat, előítéleteket. Az előítélet irányulhat a társadalom bármely jelenségére, személyére, csoportjára, köztük a fogyatékos személyek alkotta csoportra is (Allport 1977). Aronson (1999) az elöítélettel kapcsolatosan a következő meghatározást fogalmazta meg: „ellenséges vagy negatív attitüd valamilyen csoporttal szemben - olyan attitüd, amely téves, vagy nem teljes információkból származó általánositásokon alapul" (Aronson 1999: 185.).

A sztereotípia fogalma Walter Lippmanntól származik. Megfogalmazása szerint a sztereotípiák az emberek „fejében” lévő leegyszerűsített, egyoldalú és sematikus képek, amelyek segítenek az adott személynek, hogy képes legyen eligazodni bonyolult világunkban úgy, hogy annak jelenségeit kategóriákba foglalják. A társadalmi csoportok kapcsán a sztereotípiák olyan megállapítások, amelyek egy-egy társadalmi csoportra jellemzőnek tartott tulajdonságokra utalnak, közmegegyezésen alapulnak, és időben meglehetősen tartósan fennmaradnak, nehéz őket megváltoztatni (Csepeli 2006).

Az előítélet szoros kapcsolatban áll a sztereotípiákkal, magában hordozva a negatív elfogultságot, a túlzott általánosítást, a hiedelmeken alapuló téves ítéletet és a megalapozatlanságot. Az elöítélet sokféleképpen nyilvánulhat megः a szóbeliségtől (pl. viccek, cinikus megjegyzések, gyülöletbeszéd), a kiközösítésen át, egészen a hátrányos megkülönböztetésig, extrém esetben fizikai agresszióig és üldözésig (Allport 1977). Hátrányos megkülönböztetés esetén a csoport minden egyes tagját negatív sztereotip jellemzőkkel illetik (csoportközi elöitélet), és megnehezítik mindennapi boldogulásukat a hétköznapi élet szinte minden területén.

$\mathrm{A} z$ a kultúra, amelyben felnövünk, nagymértékben meghatározza bizonyos embercsoportokkal kapcsolatos attitüdünket, cselekedeteinket (Flamich-Hoffmann 2015). A legtöbb ember élete során korábban találkozik a fogyatékosság elöítéletes ábrázolásával, mint magával a fogyatékossággal élő személlyel (Flamich-Hoffmann 2015). A fogyatékosságnak a nép-és mümesékben található ábrázolásmódjai - melyek legtöbbje negatív sztereotípiát hordoz (Agbaw 2011) - kisgyermekkorunkban, mesehallgatás közben szinte észrevétlenül épülnek be tudatunkba, meghatározva a fogyatékossággal élő személyekhez való viszonyulásunkat (Beckett et al. 2010). Ehhez adódnak hozzá a közvetlen környezetünk fogyatékosságról alkotott kulturális-társadalmi mintái, mo- 
delljei, melyek szintén hatással vannak fogyatékossággal élő emberekkel kapcsolatos gondolkodásmódunkra (Davis-Wattson 2002).

Az elfogadás támogatásához megelőző intézkedésekre van szükség, hogy a többségi tanulóknak lehetőségük legyen arra, hogy megismerkedhessenek a fogyatékossággal mint fogalommal. Miután a befogadás egyik alapvető feltétele az ismeret, a tudás (Flamich-Hoffmann 2015), a fogyatékossággal élő emberek befogadásához, elfogadásához meg kell teremteni a lehetőséget arra, hogy a többségi tanulók reális, evidenciaalapú tudásra tegyenek szert a fogyatékossággal élő embereket illetően, amelyek segítségével a velük kapcsolatos korábbi elképzeléseiket újragondolhatják, felülírhatják.

\section{Fogyatékosság és gyermekirodalom}

$\mathrm{A} z$ irodalmi művek olvasása közben a tanulók lehetőséget kapnak arra, hogy önmagukról, másokról, illetve az őket körülvevő világról tájékozódjanak (Norton-Norton 2010). Prater, Dyches és Johnstun (2006) megfogalmazása szerint az irodalmi alkotások ablakot nyitnak a világra, a történeteken keresztül a tanulók megtapasztalhatják mások életét és kitekinthetnek saját tapasztalataikból. Az irodalmi müvek ugyanakkor tükörként is funkcionálhatnak, lehetőséget kínálva a tanulóknak az önreflexióra, illetve arra, hogy felismerjék a hasonlóságokat és a különbségeket saját maguk és az irodalmi alkotások szereplöi között (Gilmore-Howard 2016).

A gyermekirodalom tartalma a társadalmi változások egyik fontos indikátora, mivel az egyes kisebbségi csoportokhoz való társadalmi viszonyulás nyomon követhető a müvekben található ábrázolásmódokban. Tehát a fogyatékossággal élő személyekhez füződő aktuális társadalmi viszony jól tükröződik az irodalmi művek fogyatékosságképében (Prater-Dyches-Johnstun 2006).

Történelmi távlatokban a híres mesék, mint $A$ szépség és a szörnyeteg vagy a Tüzmanócska eredete 4000-5000 éves múltra tekint vissza (Flood 2016). Ezekben a történetekben a mássággal felruházott személy általában a főhős morális fejlődését segíti elő (Dyches-Prater-Cramer 2001). A 19. századi könyvekben található fogyatékosságreprezentációk a fogyatékossággal élő embereket mint a szenvedés tárgyait mutatják be, akik szánalmasak és terhére vannak a társadalomnak (Greta 1986). Carlisle (1998) az 1940-es évektől az 1980-as évekig tartó időszakban megjelent jelentős gyermekirodalmi müvek fogyatékosságképét vizsgálva megállapította, hogy a fogyatékossággal élö karakterek egyre nagyobb számban jelennek meg ezekben a müvekben, de a szövegek nagy része változatlanul negatív üzenetet közvetít. Harrill és munkatársai rámutatnak, hogy az 1978 után született irodalmi alkotások egy részében a fogyatékossággal kapcsolatos negatív sztereotípiák és a megkülönböztető nyelvhasználat kismértékben csökkent (Harrill et al. 1993). Ugyanakkor ezekben az irodalmi alkotásokban már megjelenik a fogyatékossággal élő személyek reális ábrázolásmódja is (Prater 2003). Ayala (1999) ugyancsak a 20. század második felében született gyermekirodalmi müveket vizsgálva rávilágít, hogy az elemzett alkotások mindössze 20 százalékában található valósághü fogyatékosábrázolás. Ráadásul az e korszakban született gyermekirodalmi művek számos esetben tartalmaznak hiedelmeket, olyanokat, mint „a vakság szeretettel gyógyítható" (Hughes 2006). Ezekben a könyvekben ismét felerősödtek a negatív sztereotípiákkal átszőtt ábrázolásmódok, mintegy tükrözve a demográfiai trendeket és a társadalomba visszatérő előítéletes szemléletmódot (Hodkinson-Park 
2017). A 21. századi gyermekirodalmak fogyatékosságképének elemzése feltárja, hogy a negatív sztereotípiák még napjainkban is jelen vannak a gyermekirodalmi alkotásokban (Beckett et al. 2010). Quayson (2007) kiegészíti ezt azzal a megállapítással, hogy a gyermekirodalmak félelmetes, negatív személyiségjegyekkel felruházott fogyatékos szereplői az olvasókból nem tetsző érzéseket váltanak ki, emiatt a gyerekek általában nem szeretik ezeket a karaktereket. Almerico (2014) rámutat, hogy az irodalmi müvek szereplői nagyon erős hatással vannak a gyerekekre, majdnem olyan intenzív hatással bírnak, mint azok az emberek, akikkel a valóságban találkoznak, akiket valóban ismernek. A gyermekirodalmak negatív, sztereotípiákkal átszőtt fogyatékosábrázolása jelentősen hozzájárulhat ahhoz, hogy a gyermekek általában félelemmel tekintenek a fogyatékossággal élő emberekre. Wall-Crevecoeur (2001) rávilágít, hogy ez a problematikus megjelenítés negatív hatással lehet az olvasónak a fogyatékossággal élő emberekkel kapcsolatos attitüdjére is.

\section{A kutatás elméleti hátterét adó fogyatékossággal kapcsolatos elemzések}

A fogyatékossággal kapcsolatos tankönyvelemzések, illetve gyermekirodalmi müelemzések szorosan kapcsolódnak az inkluzív oktatás témaköréhez. Az inkluzív oktatás kutatásának lassan fél évszázadra visszatekintő hagyományai vannak, amelyek rávilágítanak azokra a feltételekre, amelyek a befogadó oktatás sikeres megvalósításához szükségesek. Ezek közül az egyik az, hogy az inkluzív osztálytermekben szükség van inkluzív könyvekre, tankönyvekre, amelyekben megtalálhatóak a reálisan ábrázolt fogyatékossággal élő emberek is (Cameron-Rutland 2006). Ahhoz, hogy ez a kritérium megvalósuljon, szükség van a jelenlegi tankönyvek fogyatékossággal kapcsolatos tananyagtartalmának elemzésére, a bennük lévő fogyatékossággal kapcsolatos sztereotípiák feltárására (Beckett et al. 2010), illetve ezeknek a sztereotip tartalmaknak tankönyvekből való eltávolítására (Prater-Dyches-Johnstun 2006).

Jelen tanulmány a magyarországi irodalomtankönyvek és -olvasókönyvek irodalmi szemelvényeiben fellelhető fogyatékosságtartalmának feltárására és elemzésére vállalkozott. Az elemzés alapjául a Bogdan és Biklen (1977), Rubin és Strauss Watson (1987), illetve Marshall (2012) kutatásai során feltárt sztereotip ábrázolásmód-kategóriák szolgáltak, mivel ezek a kutatások részletes, komplex leírását adják az irodalmi müvekben fellelhető fogyatékosságkaraktereknek.

Bogdan és Biklen (1977) a fogyatékossággal élö emberekkel kapcsolatos sztereotip ábrázolásmódokat tíz kategóriába rendezte:

1. A fogyatékossággal élő ember mint szánalomra méltó: Az adománygyưjtő hirdetések előszeretettel alkalmazzák ezt az ábrázolásmódot. Ebben a megjelenési formában a fogyatékossággal élő személy szerethető, de nagyon sajnálatra méltó.

2. A fogyatékossággal élő személy, aki eröszakos cselekmény áldozatává válik: Ennek a megjelenítésnek az alapja az a hiedelem, miszerint a fogyatékossággal élö személy fogyatékosságából adódóan képtelen önmagát megvédeni az oot ért támadásokkal szemben.

3. Gonosz fogyatékossággal élő személy: A legtöbb népmesében megtalálható az a fogyatékossággal élő karakter, aki rossz szándékú és akadályozza a főhőst (púpos, vasorrú boszorkány, kis növésű manó vagy törpe, végtaghiányos vagy félszemü kalóz). 
4. A fogyatékossággal élő személy mint háttérszereplö: Ezeknek a szereplőknek a személyisége többnyire kidolgozatlan, éppen csak felbukkannak a történetben és nincs is benne jelentős szerepük, mint például egy vak zenész vagy egy végtaghiányos koldus.

5. Bámulatra méltó képességekkel felruházott fogyatékossággal élő személy: Gyakori jelenség a gyermekirodalomban, hogy a fogyatékos személyeket olyan képességekkel ruházzák fel, amelyek a valóságban nem léteznek, ezáltal képessé téve őket arra, hogy túlteljesítsék a fogyatékossággal nem rendelkező szereplőket.

6. A fogyatékossággal élő ember mint nevetség tárgya: Sok esetben alkalmaznak az írók fogyatékossággal élő emberekkel kapcsolatos vicceket, hogy könnyedebbé tegyék az irodalmi alkotások szövegét. A történetekben leggyakrabban a vak és gyengén látó emberek válnak a célpontjaivá tréfáknak és csínyeknek, kihasználva fogyatékosságukat.

7. A fogyatékossággal élő ember mint önmaga ellensége: Jellegzetes ábrázolásmódja az önmagát sajnáló fogyatékossággal élő szereplőnek, aki, ha tehetné, beburkolózna önnön bánatába. Ez a karakter a külvilággal jellemzően nem vagy nehezen teremt kapcsolatot. Ez a megjelenítés elveti a társadalom felelősségét a fogyatékossággal élő emberekkel történő kapcsolatteremtésben és kizárólag a fogyatékossággal élő személyt teszi felelőssé magányosságáért.

8. A fogyatékossággal élö személy mint teher a társadalom számára: Ez a karaktertípus a fogyatékossággal élő személyt a társadalom számára feleslegesként mutatja be, olyan emberként, aki képtelen értékeket létrehozni, képviselni és hathatósan részt venni a társadalmi folyamatokban.

9. A fogyatékossággal élő ember mint aszexuális szereplő: A fogyatékossággal élő karakterek általában nem élnek párkapcsolatban, nem füzik őket érzelmi szálak senkihez.

10. A fogyatékossággal élő személy, aki képtelen teljes mértékben részt venni a mindennapi életben: Szinte az egyik leginkább elterjedt hiedelem, miszerint a fogyatékossággal élő emberek nem képesek teljes életet élni sem mint családtagok, sem pedig mint dolgozó emberek. Ez az ábrázolásmód jelentősen megnehezíti a fogyatékossággal élő emberek társadalmi részvételével kapcsolatos elöítéletes gondolkodás megszüntetését, illetve a fogyatékossággal élő személyek értékeinek és képességeinek elismerését.

Rubin és Strauss Watson (1987) egy sztereotípiakategóriával gazdagította a Bogdan és Biklen sztereotípiatípusainak listáját.

11. A fogyatékosággal élő személy, aki elszigetelten él a „nem fogyatékosok” társadalmától: A fogyatékossággal élő karakterek gyakran magányosan, társadalmi kapcsolatokat nélkülöző személyként jelennek meg az irodalmi müvekben.

Marshall (2012) pedig egy újabb sztereotípiatípust adott hozzá az előbb felsorolt ábrázolásmódokhoz.

12. A fogyatékossággal élő személy, aki gyerekes, nem tud felnöttként viselkedni: A fogyatékossággal élő személyek infantilis, csupán elsődleges biológiai szükségleteikre fókuszáló élőlényként vannak jelen az irodalmi müvekben.

A szakirodalmi áttekintés rávilágít, hogy az előbb említett sztereotípiatípusok, amelyek többsége negatív sztereotípia, megtalálhatóak azokban a gyermekirodalmi mü- 
vekben, amelyeket a mai gyerekek olvasnak az iskolákban, illetve amelyeket az olvasni nem tudók hallgatnak az óvodákban (Ayala 1999; Beckett et al. 2010; Hodkinson 2007; Hughes 2006; Prater 2003). A sztereotip tartalmak feltárása, tudatosítása különösen azért jelentős, mert ezek a sokszor rejtett tartalmak képesek a gyerekek fogyatékossággal kapcsolatos felfogásmódját tudattalanul is negatív irányba mozdítani (Yokota 1993). Shakespeare (2005) szerint a gyermekirodalmi müvekben fellelhető sztereotip tartalmak, amelyek tisztázására nincs lehetőség, nagyban hátráltatják az inkluzív szemléletmód kialakulását, tudatosulását. Baglieri és Shapiro (2012) pedig rávilágít, hogy az inkluzív oktatásban elengedhetetlen feltétel az, hogy a társadalmi sokszínüség a gyermekirodalmakban is megjelenjen. Azaz, a reális módon ábrázolt fogyatékossággal élő szereplőknek is meg kell jelenniük ezekben a könyvekben.

\section{Kutatási keret}

\section{A fogyatékosság témájának megjelenése az irodalomtankönyvekben}

A tankönyvek tartalma tükrözi az adott kor társadalmának normáit, meghatározott témákhoz való hozzáállását, azonban hatással is lehet azok formálására (WhitbourneHulicka 1990). A tankönyvek tehát kapocsként szolgálhatnak a tanterv tartalma és a társadalmi felfogásmód között (Azano-Tackett-Sigmon 2017), segíthetnek feltárni és megérteni a társadalmi folyamatokat, illetve azt is, hogy ezeken milyen módon lehetne változtatni.

Jelen kutatás során arra kerestük a választ, hogy a fogyatékosság miként jelenik meg az általános iskolai olvasókönyvekben és az irodalomtankönyvekben található irodalmi művekben, illetve, hogy az irodalmi müvekben fellelhető fogyatékossággal kapcsolatos tartalmaknak milyen hatásuk lehet a tanulók fogyatékossággal élö emberekkel kapcsolatos felfogásmódjára. A vizsgálatot a következő kutatási kérdések mentén végeztük el:

- Hogyan jelenik meg a fogyatékosság a vizsgált irodalmi művekben?

- Milyen társadalmi kontextusban ábrázolódnak a fogyatékossággal élő emberek?

- Milyen fogyatékossággal kapcsolatos felfogásmód tükröződik az irodalmi művekben?

- Milyen hatással lehetnek ezek az ábrázolásmódok a tanulók fogyatékosságról alkotott felfogásmódjára?

\section{Adatgyüjtés és adatfeldolgozás}

$\mathrm{Az}$ irodalomtankönyvek irodalmi szemelvényeiben fellelhető fogyatékosságtartalom feltárására a tartalomelemzés módszerét alkalmaztuk (Krippendorff 1995; Neuendorf 2017). A kutatás első lépéseként a magyarországi általános iskolákban használt olvasókönyvek és irodalomtankönyvek kerültek leválogatásra a 2019/2020-as tanévre készült Köznevelési Tankönyvjegyzékből. A vizsgálat során 39 tankönyvben 2301 irodalmi szemelvényt vizsgáltunk meg abból a szempontból, hogy valamilyen formában megjelenik-e bennük a fogyatékosság témája. 132 irodalmi alkotásban találtunk fogyatékossággal kapcsolatos tartalmat, ezeket a müveket tovább elemeztük az előzőekben bemutatott kutatási kérdések mentén. A fogyatékossággal kapcsolatos irodalmi részletek szövegeit elkülönítettük, így ezek a szövegrészek képezték az elemzési egységeket, amelyek vizs- 
gálatát az Atlas.ti tartalomelemző szoftver használatával végeztük el. A tartalomelemzési kódrendszer kialakítása során induktív és deduktív technikákat is alkalmaztunk. Kiindulási pontként a Bogdan és Biklen (1977), Rubin és Strauss Watson (1987), illetve Marshall (2012) által összeállított, fogyatékossággal kapcsolatos sztereotípiakategóriákból alakítottuk ki az elemzés kódrendszerét. Az elemzés során azonban felmerült további kategóriák kialakításának szüksége is, így az alapkódrendszert négy további kategóriával egészítettük ki: (13) ijesztö, félelmetes karakter; (14) piszkos, ápolatlan külsejü egyén; illetve a fogyatékosság mint (15) büntetés és (16) betegség. A kódok által feltárt fogyatékossággal kapcsolatos tartalmak értelmezése lehetővé tette, hogy a kezdeti kódlistát átalakítsuk és leválogassuk, illetve csoportosítsuk azokat a kódokat, amelyek megjelennek a vizsgált irodalmi müvekben. Így egy új fókuszált és csoportosított kódrendszert kaptunk (1. ábra), amely segítségével rekurzív módon ismét elvégeztük a szövegrészek elemzését annak érdekében, hogy a lehető legpontosabban megérthessük ezek fogyatékossággal kapcsolatos tartalmának jelentését, üzenetét. A kutatás során a kódrendszer segítségével feltárt ismétlődő minták képezték a talált kifejezések értelmezésének alapját (Hoffman et al. 2011).

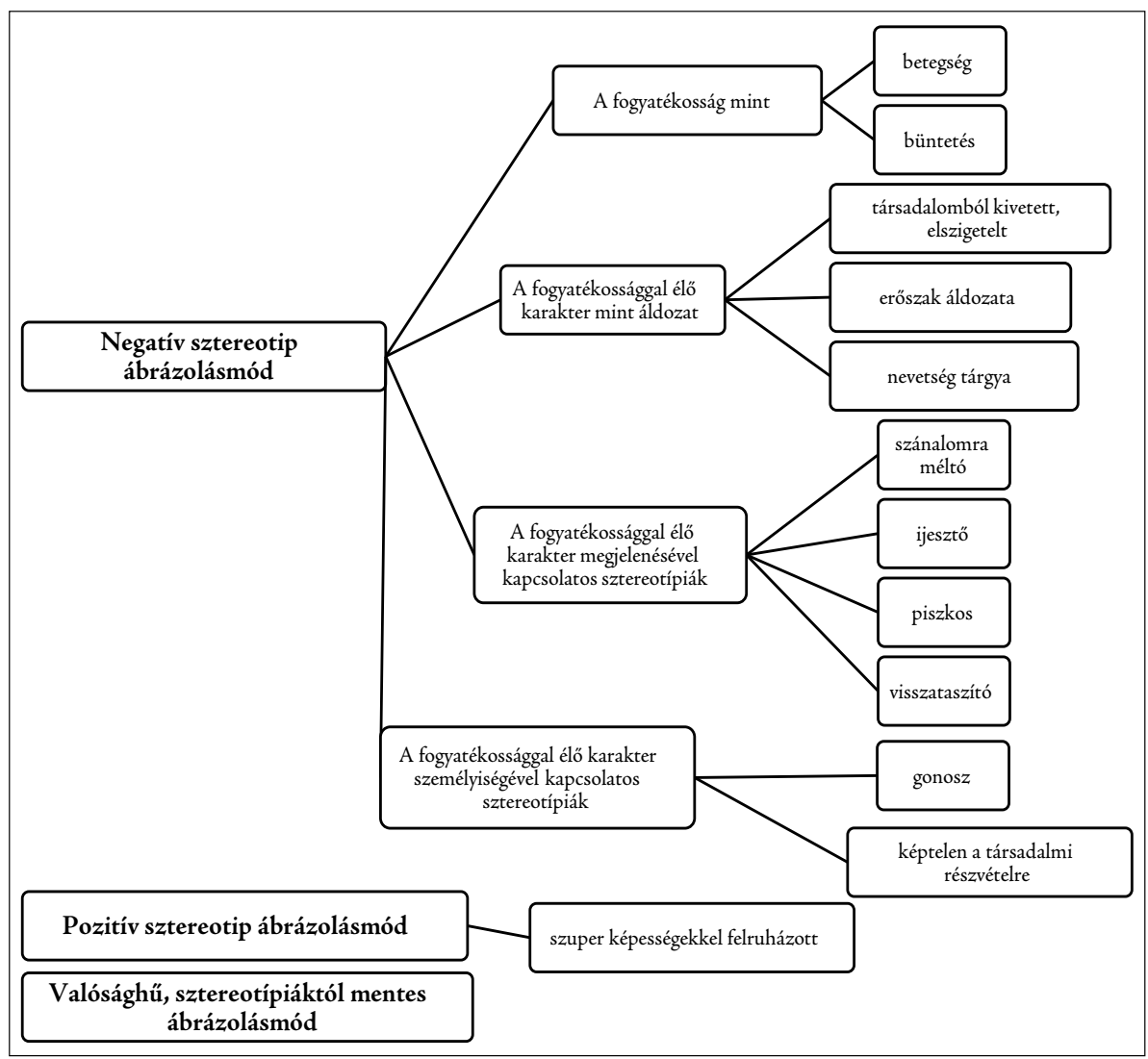

1. ábra: A tartalomelemzés kódrendszere 


\section{Eredmények és következtetések}

\section{A fogyatékosságábrázolások típusai és ezek megoszlása a vizsgált müvekben}

Az általános iskolai irodalomtankönyvekben található irodalmi szemelvények fogyatékossággal kapcsolatos tartalmának gyakorisági vizsgálata megmutatta, hogy a fogyatékosságfogalom, illetve a fogyatékossággal élő emberek mint szereplők jelen vannak a vizsgált irodalmi művekben, bár igen alulreprezentáltak (abszolút gyakoriság 132, relatív gyakoriság 0,053). Az érintett téma megjelenítése legtöbbször sztereotip felfogásmódot tükröz, az összes ábrázolás $83 \%$-a negatív sztereotípiákat tartalmaz, míg az írók 12\%-ban pozitív sztereotípiákkal ruházzák fel a fogyatékossággal élő szereplőket. A valósághü, sztereotípiáktól mentes megjelenítés igen kis mértékű, az esetek 5\%-ában volt detektálható.

A negatív sztereotípiákon belül további alcsoportokat lehetett elkülöníteni. Ezek megoszlása is igen különböző. A negatív sztereotípiát tartalmazó ábrázolásmódok nagy többsége fogyatékossággal élő személyre utal (az összes negatív sztereotípiás megjelenítés 94\%-a), míg a fogyatékosságot mint fogalmat leíró, negatív sztereotípiát tartalmazó kifejezések mindössze hat százalékát adják az ebbe a csoportba sorolt találatoknak. A fogyatékossággal élő szereplőkkel kapcsolatos negatív sztereotípiák többségben a karakter személyiségére utalnak (a negatív sztereotípiák 38\%-a).

A fogyatékossággal élő szereplők legtöbbször gonosz, kegyetlen karakterként ábrázolódnak a vizsgált müvekben, kismértékben pedig olyan szereplőként, akik képtelenek teljes mértékben részt venni a társadalmi életben (2. ábra). A fogyatékossággal élő szereplők külső tulajdonságainak megjelenítése sem mentes negatív sztereotípiáktól. Legtöbbször ijesztő alakok, akik piszkos, szakadt ruhát hordanak, sok esetben visszataszítóak, vagy szánalomra méltó külsővel rendelkeznek (2. ábra). A fogyatékossággal élő karakterek megjelenítésének egyik jellegzetes formája, hogy áldozatként vannak jelen a történetben. Sokszor válnak erőszakos cselekedet áldozataivá vagy nevetség tárgyává.

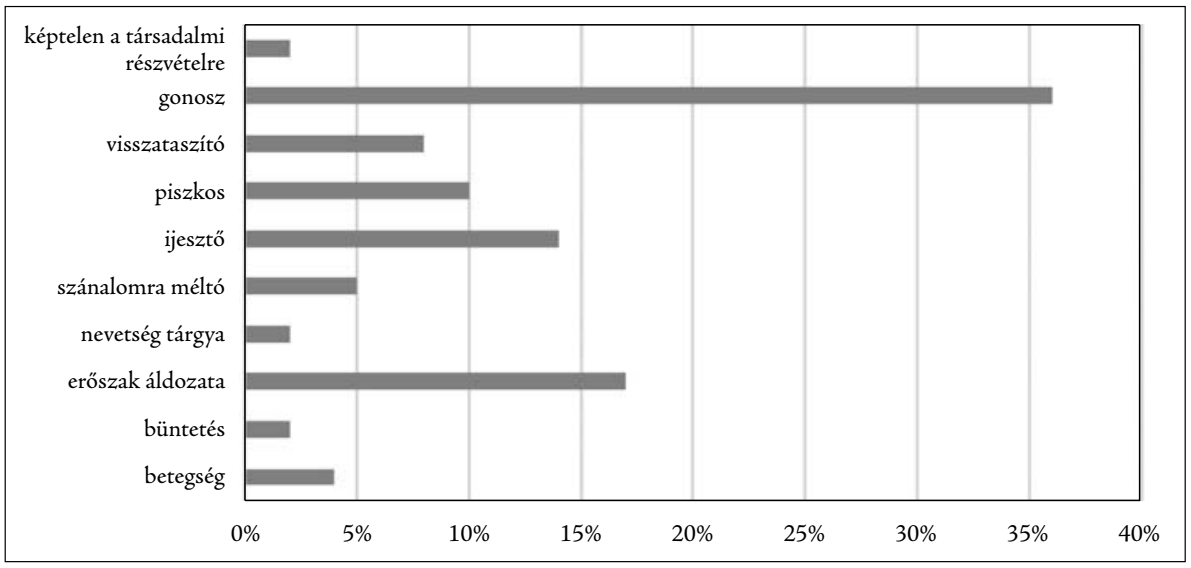

2. ábra: Az elemzett irodalmi művekben feltárt fogyatékossággal kapcsolatos negatív sztereotípiák százalékos megoszlása $(N=132)$ 
A következőkben azokat a sztereotip megjelenítéseket tárgyaljuk részleteiben, amelyek a legnagyobb arányban vannak jelen a vizsgált irodalmi alkotásokban.

\section{A fogyatékossággal élö szereplö mint gonosz}

$\mathrm{A} z$ elemzett irodalmi művekben fellelhető fogyatékossággal élő karakterek legtöbb esetben kegyetlen gonosztevőként vannak jelen a történetben. Jó példa erre Pew, a vak, akit így jellemez Stevenson Kincses sziget című müvében: „.+. sohasem hallottam ijesztőbb, bidegebb, csúnyább hangot, mint ezé a vak emberé. Ettöl még jobban megijedtem, mint a fájdalmas szoritástól..." A vak koldus személyiségéről festett negatív képet tovább erősíti a szerző azáltal, hogy a történetben való megjelenésekor elsődleges célja az, hogy elégtételt vegyen egy nem fogyatékos karakteren.

Ez az ábrázolásmód megegyezik Dabl (1993) azon állításával, miszerint a fogyatékossággal élő karaktereket gyakran mutatják be olyan helyzetekben, amikor egy nem fogyatékos szereplőn akarnak bosszút állni. Ez a megjelenítési mód azt sugallhatja az olvasónak, hogy a fogyatékossággal élő emberek sokszor másokat vádolnak és előszeretettel torolják meg az őket ért valós vagy kitalált sérelmeket (Hodkinson 2019).

Egy másik jellegzetesen gonosz karakter a Fehérlófiában jelenik meg, Hétszünyü Kapanyányimonyók, a törpe, aki a történetben erőszakkal elveszi a mások által elkészített ételt, ráadásul a forró kását az elkészítője hasáról eszi meg, vélhetően fájdalmat és égési sérülést okozva ezzel áldozatának. Az ilyen típusú ábrázolásmód könnyen negatív elöítéletekhez vezethet a fogyatékossággal élő személyekkel kapcsolatban, mivel ezek a karakterek általában nemtetszést, ellenszenvet váltanak ki az olvasókból. Ráadásul ezek a nézetek valósághűvé válhatnak és a fogyatékossággal élő személyektől való félelemhez vezethetnek, amikor a tanuló azt gondolja, hogy a fogyatékos karakterjegyek meghatározzák a fogyatékossággal élő ember személyiségét (Solis 2004). Ez a valóságtól távol álló hiedelem szerepet játszik abban, hogy az emberek nagy része idegenkedik a fogyatékossággal élő emberektől fizikai megjelenésük miatt (Quayson 2007).

\section{A fogyatékosság mint probléma vagy büntetés}

Az elemzésre került irodalmi müvekben szembetűnő volt a fogyatékosság és a tökéletesség szembeállítása. A fogyatékosság általában mint probléma, hiba jelenik meg a jellemzett szereplö külsején vagy személyiségjegyében. Például a Rege a tihanyi visszbangról című müben ezt olvashatjuk a föszereplő királylányról: „Nemcsak hogy gyönyörünek, de szelídnek, jószivünek, okosnak és türelmesnek teremtette a Jóisten, csakhogy néma volt." A mü a királylány szépségét, jóságát (amelyek pozitív tulajdonságok) szembeállítja a némaságával (amely ebben a kontrasztban negatív tulajdonságnak értelmezhető). Egy másik példa Lackfi János Apám kakasa című versében található: „Láttam már félszemü kandúrt, biztositlak jól elrandult!” A költő itt egyértelműen kifejezi, hogy a fogyatékossá válással a szereplö elveszíti szépségét is.

Számos irodalmi müben jelenik meg a fogyatékosság mint bün vagy büntetés. Kányádi Sándor A néma tulipán című történetében a gonosz kertész büntetése az, hogy törpévé zsugorodik. Dante Isteni szinjátékában a pokol kapujában „meglátod a keserü népet, a sok gonoszt s eszeveszett bolondot". A költő a gonosz lelkekkel azonos szintre helyezi a bolondokat, azaz az értelmi fogyatékossággal élő embereket. Rájuk is hasonló büntetést 
ró ki, mint a gonosz emberekre, ezzel egyenlővé teszi őket. Ebben az értelmezésben a fogyatékosság olyan, mintha bün lenne, vagy legalábbis olyan tulajdonság, ami büntetendő.

Ez a felfogásmód azt közvetítheti a tanulók felé, hogy csak a „normális”, fogyatékosság nélküli külső elfogadható a társadalom számára (Santiago 2007), a mássággal élő emberekre pedig a büntetés, a kitaszítottság vár.

\section{A fogyatékossággal élö szereplö, aki eröszak áldozata}

A kutatás eredményei között hangsúlyos, gyakran ismétlődő mintázatként van jelen az irodalmi müvek fogyatékossággal kapcsolatos tartalmában az a jelenség, hogy a fogyatékossággal élő szereplő általában meghal vagy megsérül a történetben. Ráadásul az esetek nagy többségében erőszak áldozata lesz. Ez a végkifejlet az esetek többségében szükséges a többi karakter boldogságához, a „boldogan éltek, míg meg nem haltak” befejezéshez. Stevenson Kincses sziget című regényében Pew, a vak ember a lovak alá esik, amik összetapossák, a néma királylány a Rege a tihanyi visszhangról címü müben a Hullámkirály haragjának esik áldozatul. Lackfi János az Apám kakasa címü versében pedig ekképp ír a félszemü kandúrról: „S ha a harcban nem nyuvadsz ki, hát apám fog agyoncsapni!" Ady fekete zongorája, amelyet bolond jelzővel illet, sír, nyerít és búg, azaz szenved, mert vak mestere tépi, cibálja. Gárdonyi Géza Egri csillagok című müvének félszemü karakterét, Jumurdzsákot pedig félholtra verve találják meg a várfal alatt.

Ezekben a sorokban valódi erőszakos cselekményeket olvashatunk, amelyek megalázóak, sokszor fájdalmasak vagy végzetesek az elszenvedő, fogyatékossággal élő karakter számára. A fogyatékossággal élő szereplők ilyenfajta megjelenítése azt a tévhitet táplálhatja az olvasóban, hogy a fogyatékos test gyakran könnyü célpontja a nem fogyatékos személyek által elkövetett erőszakos cselekedeteknek (Goodley-Runswick-Cole 2011).

\section{Összegzés és konklúzió}

Jelen tanulmány a magyarországi általános iskolák irodalomtankönyveiben található irodalmi müvek fogyatékosságreprezentációját tárta fel, illetve elemezte. Az eredmények azt mutatják, hogy a vizsgált irodalmi alkotásokban a fogyatékossággal élő karakterek többnyire sztereotip módon jelennek meg. A sztereotip ábrázolásmód nagy része negatív sztereotípiákkal ruházza fel a szereplöket. A legjelentősebb negatív sztereotípiák fó visszatérő mintázatai között szerepel a fogyatékossággal élő szereplő mint gonosz, a fogyatékosság mint büntetés, illetve a fogyatékossággal élő szereplő mint erőszak tárgya. Az elemzett irodalmi müvek erőteljesen tükrözik azt a felfogásmódot, amely szerint a „normától” való fizikai vagy szellemi jellegű eltérés mindig elítélendő, negatív. Santiago (2007) szerint ennek a megközelítésnek az lehet a következménye, hogy a tanulók erősen normaorientáltakká válnak, és nehezen fogadnak el olyan személyeket, akik ettől a társadalom által meghatározott és elfogadott kritériumrendszertől különböznek. Így a társadalmi diverzitás fogalmának adaptálásával, a különböző kisebbségi csoportok tagjainak elfogadásával kapcsolatosan problémáik merülhetnek fel.

Ezek az eredmények felhívják a figyelmet arra, hogy a jelenlegi irodalmi szemelvények nem inkluzívak, alapvetően a fogyatékosság morális modelljének felfogásmódját tükrözik. Nem segítik elő a fogyatékossággal élő emberek megismerését, inkább fé- 
lelmet sugallnak velük kapcsolatban és az elszigeteltségükhöz vezethetnek. Az ilyen kirekesztő jellegű, egyoldalú fogyatékosság-ábrázolásmód a műveket olvasó tanulók fogyatékossággal élő emberekkel kapcsolatos elöítéleteit erősítheti és akadályt képezhet a társadalmi inklúzió megvalósításában (Hodkinson 2017).

Az elemzett irodalmi művek kritikai elemzés nélküli alkalmazása nem javasolt az irodalomórákon. A szépírók által alkalmazott sztereotípiák feltárása bizonyítékul szolgálhat a tanulók számára, hogy a fogyatékossággal élő emberekkel kapcsolatos elöítéletek évszázadok óta léteznek. Ugyanakkor a sztereotípiák elemzése segíthet újragondolni a tanulók saját, a fogyatékossággal élő emberekhez kapcsolódó elöítéleteit (FlamichHoffmann 2014). Ezért ezeknek az irodalmi müveknek a feldolgozásakor hangsúlyt kell fektetni a fogyatékossággal kapcsolatos sztereotip ábrázolásmód kritikus vizsgálatára. Ugyanakkor hasznos lenne, ha az irodalomtankönyvekben megjelennének inkluzív irodalmi alkotások is, hiszen, ahogy Prater, Dyches és Jobnstun (2006) kutatásának eredményei mutatják, kizárólag az „inkluzív irodalom” az, amely minden gyermek számára vitathatatlanul hasznos lehet. A nem csupán fikción alapuló inkluzív olvasmányok ugyanis tükrözik a társadalmi diverzitást, ugyanakkor ezek az irodalmi művek hozzájárulnak a fogyatékossággal élö tanulók pozitív énképének kialakulásához is (Beckett et al. 2010). Ezek pedig elengedhetetlen feltételei a fogyatékossággal élő személyek társadalmi beilleszkedésének és befogadásának.

\section{IRODALOM}

Agbaw, Y. (2011) Reading Disability in Children's Literature: Hans Christian Anderson's Tales. Journal of Literacy E Cultural Disability Studies, Vol. 5. No. 1. pp. 91-107.

Allport, G. (1977) Az elöitélet. Budapest, Gondolat.

Almerico, G. (2014) Building Character through Literacy with Children's Literature. Research in Higher Education Journal, Vol. 26. No. 1. pp. 1-14.

Aronson, E. (1999) The Social Animal. (Eight edition.) New York, Worth Publishes, Inc.

Ayala, E. (1999) "Poor Little Things", and "Brave Little Souls": The Portrayal of Individuals with Disabilities in Children's Literature. Reading Research and Instruction, Vol. 39. No. 1. pp. 103-117.

Azano, A., Tackett, M. \& Sigmon, M. (2017) Understanding the Puzzle behind the Pictures: A Content Analysis of Children's Picture Books About Autism. AERA Open, Vol. 3. No. 2. pp. 1-12.

Baglieri, S. \& Shapiro, A. (2012) Disability Studies and Inclusive Classroom. Oxon, Routledge.

Beckett, A., Ellison, N., Barrett, S. \& Shah, S. (2010) 'Away with the Fairies?' Disability within Primary School Age Children's Literature. Disability and Society, Vol. 35. No. 3. pp. 373-386.

Bogdan, R. \& Biklen, D. (1977) Media Portrayals of Disabled People: A Study in Stereotypes. Interracial Books for Children Bulletin, Vol. 6. Nos 6-7. pp. 4-9.

Cameron, L. \& Rutrand, A. (2006) Extended Contact through Story Reading in School: Reducing Children's Prejudice Toward The Disabled. Journal of Social Issues, Vol. 62. No. 3. pp. 469-488.

Carlisle, M. (1998) Portrayal of People with Disabilities in Children's Literature: 1940s to 1980s. Retrieved from Beta Phi Mu (Indiana University). http://bpm.slis.indiana.edu/ scholarship/carlisle.shtml. [Letöltve: 2020. 07. 22.] 


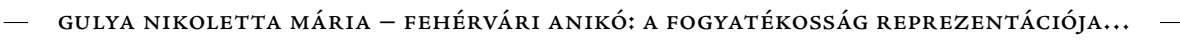

Connor, D. \& Bejoian, L. (2014) Cripping School Curricula: 20 Ways to Re-Teach Disability. Review of Disability Studies, Vol. 3. No. 3. pp. 3-13.

Csepeli, GY. (2006) Szociálpszichológia. Budapest, Osiris Kiadó.

DAHL, M. (1993) The Role of the Media in Promoting Images of Disability-Disability as metaphor: The Evil Crip. Canadian Journal of Communication, Vol. 18. No. 1. pp. 75-80.

Davis, J. \& Wattson, D. (2002) Countering Stereotypes of Disability: Disabled Children and Resistance. In: M. Corker \& T. Shakespeare (eds) Disability/Postmodernity: Embodying Disability Theory. London, Bloomsbury. pp. 159-174.

Dyches, T., Prater, M. \& Cramer, S. (2001) Characterization of Mental Retardation and Autism in Children's Books. Education and Training in Mental Retardation and Developmental Disabilities, Vol. 36. No. 3. pp. 230-243.

ERős F. (2007) Irányok és tendenciák az elöítéletek kutatásában. Educatio, Vol. 16. No. 1. pp. 3-9.

Flamich M. \& Hoffmann R. (2014) Fogyatékos hősök mesékben és a mindennapokban, a kulturális fogyatékosságtudomány szerepe a pedagógusképzésben. In: Koós I. \& Molnár B. (eds) A tanitóképzés múltja, jelene III. Sopron, Nyugat-magyarországi Egyetem Kiadó. pp. 56-67.

Flamich M. \& Hoffmann R. (2015) Meddig kísért még a múlt? A kulturális fogyatékosságtudomány szerepe, perspektívái a diverzitás megismerésében, elfogadásában és tiszteletében. In: Hernádi I. \& Könczey Gy. (eds) A felelet kérdései között. Budapest, ELTE BGYK. pp. 48-68.

Flood, A. (2016) The Guardian: Fairytales Much Older Than Previously Thought, Say Researchers. The Guardian Newspaper. https://www.theguardian.com/books/2016/ jan/20/fairytales-much-older-than-previously-thought-say-researchers [Letöltve: 2020. 08. 10.]

Foucault, M. (1991) A diskurzus rendje. Holmi, Vol. 3. No. 7. pp. 868-889. http://holmi. org/pdf/archive/holmi1991-07.pdf. [Letöltveः 2020. 09. 28.]

Gilmore, L. \& Howard, G. (2016) Children's Books that Promote Understanding of Difference, Diversity and Disability. Journal of Psychologists and Counsellors in Schools, Vol. 26. No. 2. pp. 218-251.

Goodley, D. \& Runswick-Cole, K. (2011) The Violence Of Disablism. Sociology of Health E Illness, Vol. 33. No. 4. pp. 602-617.

GöDőNÉ TöRöK I. (2011) A könyv, az irodalom mint az értékközvetítés és a lelki egészség megőrzésének eszköze. Képzés és Gyakorlat, Vol. 9. Nos 1-2. pp. 195-204.

Greta, L. (1986) “Handicapped Characters in Children's Literature: Yesterday and today.” Children's Literature Association Quarterly, Vol. 10. No. 4. pp. 181-184.

Guinagh, B. (1980) The Social Integration of Handicapped Children. The Phi Delta Kappan, Vol. 62. No. 1. pp. 27-29.

Hardin, M. \& Preston, A. (2001) Inclusion of Disability Issues in News Reporting Textbooks. Journalism E Mass Communication Educator, Vol. 56. No. 2. pp. 43-54.

Harrill, J., Leung, J., Mckeag, R. \& Price, J. (1993) Portrayal of Handicapped/Disabled Individuals in Children's Literature: Before and after Public Law 94-142. University of Wisconsin-Oshkosh. (ERIC Document Reproduction Services No. ED 357557.)

Hodkinson, A. (2007) Inclusive Education and the Cultural Representation of Disability and Disabled People: A Recipe for Disaster or the Catalyst for Change? An Examination of Non-Disabled Primary School Children's Attitudes to Children With a Disability. Research in Education, No. 77. pp. 56-76. 
Hodkinson, A. (2017) Constructing Impairment and Disability in School Reading Schemes. Education 3-13, Vol. 45. No. 5. pp. 572-585.

Hodkinson, A. (2019) The Unseeing Eye: Disability and the Hauntology of Derrida's Ghost-An Analysis in Three Parts. Qualitative Inquiry. https://doi.org/ $10.1177 / 1077800419847429$

Hodkinson, A. \& Park, J. (2017) 'Telling Tales'. An Investigation into the Representation of Disability in Classic Children's Fairy Tales. Educational Futures, Vol. 8. No. 2. pp. 48-68.

Hoffmann, J., Wilson, M., Martinez, R. \& Sailors, M. (2011) Content Analysis: The Past, Present, and Future. In: K. Duke \& M. Mallette (eds) Literacy Research Methods. New York (NY), Guilford. pp. 29-49.

Hughes, C. (2012) Seeing Blindness in Children's Picture Books. Journal of Literacy and Cultural Disability Studies, Vol. 6. No. 1. pp. 35-51.

Köpatakiné Mészáros M., Mayer J. \& Singer P. (2006) Élethosszig tanulni, de hogyan? Új Pedagógiai Szemle, Vol. 56. No. 10. pp. 87-113.

Krippendorff, K. (1995) A tartalomelemzés módszertanának alapjai. Budapest, Balassi Kiadó.

Marshall, B. (2012) Notes for Class: Disability in Literature Spring 2012. http://faculty.uml. edu/bmarshall/DisLitSpring2012NOTES.html [Letöltve: 2020. 07. 25.]

Mcdougall, J., Dewit, D., King, G., Miller, L. \& Killip, S. (2004) High Schoolaged Youths' Attitudes toward Their Peers with Disabilities: The Role of School and Student Interpersonal Factors. International Journal of Disability, Development and Education, Vol. 51. No. 3. pp. 287-313.

Neuendorf, K. (2017) The Content Analysis Guidebook. Second edition. SAGE Publications.

Norton, D. \& Norton, S. (2010) Through the Eyes of a Child: An Introduction to Children's Literature. (8th ed.) Boston (MA), Prentice-Hall.

O'brien, D., Kudlacek, M. \& Howe, P. (2009) A Contemporary Review of English Language Literature on Inclusion of Students with Disabilities in Physical Education: A European Perspective. European Journal of Adapted Physical Activity, Vol. 2. No. 1. pp. 46-61.

PLÉ Cs. (2017) Kategorizáció, sztereotípia, előítélet. Iskolakultúra, Vol. 27. No. 1-12. pp. 13-20.

Prater, M. (2003) Learning Disabilities in Children's and Adolescent Literature: How are Characters Portrayed? Learning Disability Quarterly, Vol. 26. No. 1. pp. 47-62.

Prater, M., Dyches, T. \& Johnstun, M. (2006) Teaching Students about Disability through Children's Literature. Intervention in School and Clinic, Vol. 42. No. 1. pp. 14-24.

Quayson, A. (2007) Aesthetic Nervousness: Disability and the Crisis of Representation. Chichester, Columbia University Press.

Riley, C. A. (2005) Disability and the Media: Prescriptions for Change. University Press of New England.

Rubin, E. \& Strauss Watson, E. (1987) Disability Bias in Children's Literature. The Lion and the Unicorn, Vol. 11. No. 1. pp. 60-67.

Santiago, S. (2007) Snow White and the Seven 'Dwarfs' - Queercripped. Hypatia, Vol. 22. No. 2. pp. 114-131.

Schiemer, M. (2017) Reality Bites: Listening to Children, Parents, Teachers and Other Experts. In Schiemer, M.: Education for Children with Disabilities in Addis Ababa, 


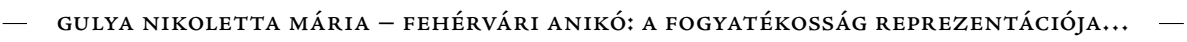

Ethiopia. (Inclusive Learning and Educational Equity, Vol. 4.) Cham, Springer. pp. $123-$ 139. https://doi.org/10.1007/978-3-319-60768-9_5

Shakespeare, T. (2005) Disability Studies Today and Tomorrow. Sociology of Health $\mathcal{E}$ Illness, Vol. 27. No. 1. pp. 138-148.

Solis, S. (2004) The Disability Making Factory: Manufacturing "Differences" through Children's Books. Disability Studies Quarterly [Online], Vol. 24. No. 1. DOI: 10.18061/ dsq.v24i1.851

Szekeres Á. (2012) Integráltan tanuló, enyhén értelmi fogyatékos gyermekek szociális helyzetének felmérése szociometria segítségével. Iskolakultúra, Vol. 22. No. 11. pp. 3-23.

Szeneres Á., Perlusz A. \& Takács I. (2012) „....egy ideális világban csak így szabadna tanítani..." Gyógypedagógusok véleménye az integrációval kapcsolatban. In: Zászkaliczky P. (ed.) A társadalmi és az iskolai integráció feltételrendszere és korlátai. Budapest, ELTE Eötvös Kiadó. pp. 201-226.

Ullah, H., Ali, Z. \& NaZ, A. (2014) Gender Representation in Children's Books: A Critical Review of Empirical Studies. World Applied Sciences Journal, Vol. 29. No. 1. pp. 134-141.

Wall, B. \& Crevecoeur, Y. (1991) Narrator's Voice: The Dilemma of Children's Fiction. New York, Palgrave Macmillan.

Wall, B. \& Crevecoeur, Y. (2001) Narrator's Voice: The Dilemma of Children's Fiction. New York, Palgrave Macmillan.

Whit boume, S. \& Hulicka, I. (1990) Ageism in Undergraduate Psychology Texts. American Psychologist, Vol. 45. No. 10. pp. 1127-1136.

Үокота, J. (1993) Issues in selecting Multicultural Children's Literature. Language Arts, Vol. 70. No. 3. pp. 56-167.

A cikk a Creative Commons Attribution 4.0 International License (https://creativecommons.org/licenses/ by/4.0/) feltételei szerint publikált Open Access közlemény, melynek szellemében a cikk bármilyen médiumban szabadon felhasználható, megosztható és újraközölhető, feltéve, hogy az eredeti szerző és a közlés helye, illetve a CC License linkje és az esetlegesen végrehajtott módosítások feltüntetésre kerülnek. (SID_1) 